\title{
Using tables to enhance trustworthiness in qualitative research
}

\begin{abstract}
In this essay, we discuss how tables can be used to ensure - and reassure about trustworthiness in qualitative research. We posit that in qualitative research, tables help not only increase transparency about data collection, analysis, and findings, but also - and no less importantly - organize and analyze data effectively. We present some of the tables most frequently used by qualitative researchers, explain their uses, discuss how they enhance trustworthiness, and provide illustrative examples to inspire readers in their use of tables in their own research.
\end{abstract}

Key words: tables, trustworthiness, matrices, matrix displays, qualitative research, data representation, visualization, qualitative data analysis 


\section{Introduction}

In qualitative research, tables serve many purposes throughout the lifecycle of a research project. They make it easy to navigate and sort large amounts of data in various ways, allowing researchers to examine them from multiple and diverse angles. They help researchers condense, bring order and make sense of data, and help them see what otherwise would be difficult - if not impossible - to see amidst the hundreds, and even thousands of pages of unreduced, textual data, which constitute the basis of most qualitative studies. And finally, done well, tables help researchers communicate research findings and theoretical insights in a parsimonious, easy to understand and convincing way.

Despite their versatility and usefulness, however, tables are not without their critics. Some scholars view them as reductionist and accept them only as a necessary evil. They warn against the overuse of tables and the travesties that they may cause, including the force-fitting of data into categories and the eroding of the richness that is qualitative research's main strength as compared to other research methods (Nadin and Cassell, 2004, Pratt et al., 2020a). The range of their different uses in qualitative research is also not widely understood, as many scholars tend to think of them primarily (and often only!) as communication devices, to be used as a "smart write-up strategy to enhance publication chances" (Jonsen et al., 2018) without considering their other uses, notably for supporting data analysis and ensuring trustworthiness. We address these issues in turn.

First, many of the criticisms targeted at tables are not due to their characteristics as such but to their often being associated - erroneously in our view - with particular methodological approaches or ontological perspectives. For example, the popularity of the so-called Gioia method (Gioia et al., 2013), which encourages the use of particular types of tables, has led some to conflate the use of tables with this methodological approach. 
While the confusion is understandable, tables should not be viewed as a proprietary feature of any particular methodological or analytical approach. In fact, they are used by scholars in various traditions, including those who favor the case study method (Eisenhardt, 1989a) as well as those who do ethnography (Jarzabkowski et al., 2014).

Likewise, tables tend to be viewed as the preferred tool of scholars whose qualitative work reflects a realist ontology. Consequently, when editors and reviewers suggest the use of tables, this tends to be interpreted as pressure to conform to more positivist forms of qualitative research. Miles and Huberman, who advocated an ample use of tables in qualitative research, maintained that "social phenomena exist not only in the mind but also in the objective world and that some lawful and reasonably stable relationships are to be found among them" (1994: 4), which may partly explain this misconception. In our view, however, conflating the use of tables with a realist ontology or a positivistic orientation, is a mistake. Tables, in and of themselves, are ontologically and epistemologically neutral. They are merely tools in the hands of researchers who find them useful for accomplishing various research tasks, regardless of one's research orientation or choice of method.

Second, tablesmust be viewed as more than just communication devices. While they are certainly useful for relaying information about research sites and methods, summarizing observations, and/or displaying data points, they are also useful as analytical devices to arrange data in a way that facilitates or permits comparisons, allowing researchers to detect similarities and differences and notice patterns, including co-occurrences, themes, and trends (Miles and Huberman, 1994), activities which are essential for interpreting qualitative data. In our experience, many of the tables that eventually end up in our manuscripts are the polished and trimmed version of tables produced earlier on, which were 
developed to make sense of our data in the first place. In fact, it is not uncommon for us to start writing a paper only after having produced a set of tables that condense theoretical insights and reassure us about their grounding in the data. The act of building tables is thus central to our immersion in and understanding of the data.

Finally, and in keeping with a rising conversation around the trustworthiness of qualitative research (Pratt, Kaplan \& Whittington, 2020; Lincoln \& Guba, 1985; Yin, 2003; Reinhardt, Kreiner, Gioia \& Corley, 2017), we argue that tables are useful devices to help ensure - and reassure - readers about the trustworthiness of their research process and the robustness of the data backing the conclusions they draw. By trustworthiness, we mean "the degree to which the reader can assess whether the researchers have been honest in how the research has been carried out and reasonable in the conclusions they make" (Pratt, Kaplan \& Whittington, 2020: 2). Prior work has proposed different criteria for trustworthiness in qualitative research, reflecting either a naturalistic (Guba \& Lincoln, 1985) or positivistic (Yin, 2003) perspective. While these criteria differ in their language, there are many overlaps in their practical recommendations - both draw attention, for instance, to the importance of using multiple sources of evidence, gathering and providing rich contextual information, tracking and accounting for similarities and differences across cases, enabling the reconstruction of the researcher's analytical moves, and keeping data well-organized and easily accessible (see Pratt et al., 2020 for a comparison). Tables, we argue, can help a researcher address all of these concerns and recommendations regardless of their research orientation or methodological preferences.

If we accept an understanding of social science as, in its essence, "a sense-making activity" (Astley, 1985), and that sensemaking is essentially about bringing order into 
chaos (Weick, 1995), then - we argue - tables are useful because they help bring order into an otherwise vast and chaotic mass of data. If research is about finding and interpreting patterns (whether in events, actions, interpretations, narrative structures, etc.), then tables are useful because they enable us to connect cues (data points) in ways that help us assign meaning to our observations. If we accept the idea that "a theory tries to make sense out of the observable world by ordering the relationships by elements that constitute the theorist's focus of attention in the real world" (Dubin, 1976, p. 26), then tables provide invaluable support to the theory building effort that is central to qualitative research.

In this paper, we present an array of different table types and their possible uses (see Table 1) and explain how each type can contribute to ensuring the trustworthiness of any given qualitative research process. We posit that in qualitative research, tables typically serve three purposes: 1) they help organize and condense data; 2) they allow scholars to analyze data from various perspectives; and 3) they help display evidence and show findings in a way that is succinct and convincing to readers. Within any given study, tables can be used for only one, some or all these functions. The only limits to their use are the limits of any given scholar's imagination. The classification we propose draws mainly on our knowledge of published qualitative studies and our familiarity with this tool; it did however benefit from a careful review of qualitative research published in top journals in the last three years, as we used tables from these articles to validate, extend, refine and exemplify our classification.

\section{INSERT TABLE 1 ABOUT HERE}

\section{Organizing}

One of the most useful and important functions of tables is to help organize and manage the large amount of data that qualitative researchers typically collect (Camoes, 2016). To 
this end, large tables that we refer to as data inventories can be useful for compiling, in a tabular form, records of available data items (interviews, documents, images, videos, etc.), which can then be organized according to any number of useful criteria (such as time, people, roles, events, activities, issues, concepts, etc. - see Patton, (2003), for a more complete list). References or links to each item might occupy the left-hand column of a table, and each adjoining column might specify information about it: when it was collected, by whom, where, by case, by source (interviews, documents, field notes, etc.), by type (meeting minutes, news report, annual report, etc.), by type of actor (CEO, VP, manager, etc.), by time, etc. ${ }^{1}$.

In case study research, for example, data inventories can increase the reliability of a study by documenting the content of a "case database" (Yin, 2003), to facilitate easy retrieval and use of these data during analysis, and ensure that all of the data required to address a research question or support certain conclusions are available. In this regard, their usefulness is not limited to case studies but extends to all qualitative studies that rely on a large, heterogeneous array of data sources. Data inventories can also be used to keep track of researcher-produced analytical decisions, memos (Saldana, 2016), contact summary forms (Miles et al., 2020) and other forms of record-keeping activities that document the research process (i.e. the inquiry audit trail, Lincoln \& Guba, 1985), all of which are necessary and important for ensuring transparency (Gephart, 2004, Pratt, 2008) and establishing trustworthiness in qualitative work (Lincoln and Guba, 1985).

\footnotetext{
${ }^{1}$ Some researchers find toggle switches in an Excel spreadsheet or CAQDAS useful to retrieve or count data items for the purpose of completing data sources or analytical tables, or to respond to reviewer requests about the nature of the data collected (for example: how many informants occupied $\mathrm{x}$ role in the organizations studied?)
} 
When building a data inventory, Few (2012) suggests identifying criteria that help group and segment data items into meaningful sections and subsections that are potentially useful for portioning data into manageable chunks for analysis. Such criteria would allow a researcher to easily locate and retrieve a subset of the data items collected in order to undertake a more focused analysis on, for example, a specific case (in a multiple case study), over a specific time period (for a longitudinal study), or a specific unit of analysis. Such inventories also make it easy to prioritize or rank data items (by time, or by any other criterion of significance to a study) or sequence them in the order in which the researcher wants to read or analyze them (later accounts first, smaller organizations before larger ones, interviews before archival material, etc.).

A well maintained data inventory, properly referenced and cross-indexed (Mason, 2002) also simplifies the eventual construction of a data sources table (a table that itemizes all the data used in a specific study by type or source) or a data sources and use table (which, in addition to sources, specifies how each type of data was actually used in a study), both of which appear more and more frequently in the methods section of published qualitative work. These tables usually feature data sources by type (interviews, documentation, field notes, etc.) in the first column, and feature detailed descriptions, quantity of data collected for each type and how they were used (when including) in the adjoining columns. For typical examples, see Jarzabkowski, Lê and Balogun (2019, Table 1) or Howard-Grenville, Mayer and Metzger (2013, Table 1).

Data sources tables, which are primarily used for display purposes, are used across a wide range of qualitative methods - including ethnographic studies - to account both transparently and succinctly, but also in sufficient detail for the content of a qualitative 
database. On occasion, such tables will also provide information about when data items were collected, or specify how the researcher's role, status and responses progressed through multiple rounds of immersion in the field. By doing so, data sources tables increase trustworthiness in a study, by accounting for the "disciplined pursuit and analysis of data" (Locke \& Golden-Biddle, 1997, p. 604), and help readers assess important sources of the credibility of data and data collection procedures, such as the extent of a researchers' engagement in the field or their reliance on multiple sources (Lincoln and Guba, 1985; Yin, 2003).

When analyzing data, data sources and use tables can be particularly useful for ensuring that important parts of the database have not been overlooked. When a database includes interviews, for instance, it is not uncommon to rest one's analysis primarily on the content of these interviews, while potentially rich and insightful archival material remains underutilized. By forcing a researcher to reflect on how they used their sources, this type of table helps address this potential problem. In doing so, the tables increase trustworthiness not only by providing transparency to the empirical grounding of one's assertions but also by pushing the researcher to take full advantage of opportunities to triangulate their data across sources (Guba \& Lincoln, 1985; Yin, 2003).

Beyond tracking and organizing data, tables can also be used to start the process of condensing and synthesizing raw data into a more manageable form and structuring them for further, more in-depth analysis, which we examine next. A table listing a sequence of events (event listings), for example, can be used to keep track of the chronology of events, decisions and actions of importance to a study (see Zietsma and Lawrence, 2010, Table 1). These tables typically will place a time indicator (years, months, days, etc.) in the first 
column, with descriptions of the events or activities being documented in the adjoining columns. Likewise, tabulated case summaries help researchers keep track of and ensure that they've collected consistent information across cases and units of analysis (organizations, projects, decisions, etc.), an essential first step before comparisons between cases can be made (see Bechky \& Okhuysen, 2011, Table1, and Kaplan and Orlikowski, 2013, Table 1).

If transparency enhances trustworthiness by helping "scholars recognize circumstances that are roughly analogous to those in which earlier theories and concepts seemed to have explanatory value" (Pratt et al., 2020: 6), then constructing event lists or case summaries forces researchers to accurately reconstruct events and event sequences, as well as establish and disclose facts and conditions that constitute the historical, organizational and/or social context within which observations were gathered. This is important to ensure that interpretations are mindful of contextual conditions and how they might have influenced observed patterns. Disclosing rich contextual information in this way is essential for assessing not only the trustworthiness of a study's conclusions (i.e. was it appropriate to use (or not use) certain prior concepts in the analysis) but also their transferability to other settings (Lincoln and Guba, 1985). While this information can certainly be conveyed textually, tables help do so by presenting it in a concise, comprehensive, possibly comparative form without breaking up the main narrative.

\section{Analyzing}

As we mentioned in our introduction, tables do not serve only as communication devices. They are also analytical devices, well adapted to helping scholars navigate, get a handle on and make sense of their data, even if ultimately they are not included in the final version of a paper. When analytical tables are included (versions of which are condensed 
and trimmed for display purposes), they will usually be found in the findings section of a published paper.

If the point of data analysis is to "transform data into findings" (Patton, 2003), then tables are a useful tool for undertaking such transformation. In our experience, this often occurs in the process of designing and developing different kinds of tables, in an iterative process of condensing and displaying the data on the one hand, and drawing and verifying conclusions on the other (Miles et al., 2020). In this process, many tables will be drawn and subsequently discarded, either because the data to complete them is not available, or the table is not helpful for revealing anything new. It may take several iterations before a researcher sees something interesting or makes a revelatory insight. Tables allow researchers to play with their data - visually - in ways that reading through transcripts or documents, coding and writing memos do not, and as such are an important complement to these other approaches to analysis.

Tables are usually at their most useful once a certain corpus of data (which need not be particularly large) has been collected, sorted and organized, and some coding of the data, using grounded theory or other approaches has begun (it is important to note that the use of tables as an analytical technique is not attached to any particular coding approach). At this stage, working tables may help condense rich data from multiple sources into separate displays focused on subsets of evidence directly relevant to the research question. Doing this helps reveal gaps in the data, temporal inconsistencies, inconsistencies among sources, and other anomalies. It also allows for cross-checking to verify if certain types of evidence are present across informants or cases, and ultimately directs further data collection (see 
the Online Appendix, for more detailed examples of how multiple analytical tables supported our analysis in Cloutier and Ravasi, 2020).

When used for analytical purposes, tables also make it possible to display data in a manner that relates them to something else (such as time, or roles, or context, or concepts) and, by so doing, to reveal some meaningful pattern or insight, which otherwise would have been invisible (Few, 2012). Regardless of their type, therefore, tables must be designed in a way that facilitates or permits comparisons, detection of differences, and noting of various patterns, including co-occurrences, themes, and trends (Miles \& Huberman, 1994, p. 93). It is these comparisons which are the most useful for making sense of a study's observations.

In the following paragraphs we present seven analytical table types: concept-evidence tables, coding schemes, cross-case analysis tables, co-occurrence tables, temporallyordered tables, typologically-ordered tables and theoretical summaries. These tables are representative of those we see most often in published qualitative management research, and which we ourselves have found useful in our own work. Their cells can contain data presented in a wide variety of forms, not only raw data (taken "as is" from the data corpus) in the form of direct quotes, excerpts from field notes, or pictures, but also processed data, in the form of evaluations or narrative summaries (see Table 2 for examples) or even symbols (+ -, 0 1, tick mark, star, etc.) (Glesne, 1999) or numbers. Presenting evidence in different forms in the same table - e.g. using symbols or images, instead of text excepts for example, may reveal patterns that a researcher may not have been able to notice otherwise.

\section{INSERT TABLE 2 ABOUT HERE}


These seven types by no means exhaust the table design possibilities that exist. The variety of situations encountered by qualitative researchers is such that there is no single best way to structure tables. Different research questions, available data sources, number of cases (single vs. multiple), and the nature of theoretical claims (variance vs. process, (see Mohr, 1982) may call for different types of tables. Sometimes, combining features from different archetypal tables may be useful - or even required - to illustrate one's observations and support one's arguments. Elaborate versions of concept-evidence tables, for instance, may be used not only to show empirical support for focal constructs but also to highlight variation in the same constructs over time or compare different types of constructs, effectively turning these tables into temporally or typologically-ordered tables, as we shall discuss later.

Concept-evidence tables list all the concepts that are gradually emerging from the analysis alongside the evidence that supports them. By concepts, we refer to the basic components that arise from data coding and which appear connected to a study's emerging theoretical framework. Concepts may arise from systematic coding, as when using grounded theory (Locke, 2001, Charmaz, 2006), or from other analytical approaches (Feldman, 1995, Spradley, 1980, Spradley, 1979, Boréus and Bergström, 2017). They can include practices, processes, perceptions, beliefs, and other attributes of individuals, groups, organizations, or environments. By evidence, we refer to the data that supports these concepts.

The simplest way to structure these tables is to list concepts in the first column of a table, and then use the adjoining columns to display selected evidence. Evidence in these simple tables will often be in the form of direct quotes, but as we've mentioned before, it 
can also include excerpts from field notes, summaries of observations, graphs, or pictures. For examples see Kreiner (2015, Table 3) or Farny, Kibler and Down (2019, Tables 2a, $2 b$ and 2c). A useful variation on this format - see Sutton and Hargadon (1996, Table 1) uses multiple columns to collect evidence of different type and/or from different sources (one type or source per column) for each concept. As triangulation of sources is considered important for the credibility of case analyses (Yin, 2003) as well as other forms of qualitative research (Lincoln and Guba, 1985, Patton, 2003), doing so may help researchers reassure themselves (and later their readers) that their emerging theoretical interpretations (i.e. concepts) rest on robust empirical evidence.

Concept-evidence tables support analysis by helping to structure the sorting and ordering of selected data (such as excerpts from interview transcripts or field notes, narrative summaries of observations, factual information from archival sources, etc.). In our own research we will often do this by literally cutting and pasting fragments of text into Word tables, as we find that this process helps focus our attention on evidence directly relevant to the research question, and stimulates effortful processes of bracketing, comparing, and grouping data that effectively constitute important steps of the analytical process.

When coding, in particular, concept-evidence tables are useful to facilitate the "splitting" and "merging" of provisional codes (Grodal et al., 2020) by enabling a visual engagement with available evidence as fragments of text gradually populate working tables. In our experience, a cell gathering a disproportionate amount of quotes often indicates an opportunity to split a provisional code to produce a more fine-grained analysis. Cells gathering only scant evidence, in turn, invite us to consider merging multiple codes 
into more abstract concepts, or point to the need for further data collection to explore concepts that at the moment do not appear to be robustly supported by the data.

This being said, structured efforts at coding or tabulating evidence often do not so much produce theoretical insights as they help examine more systematically the intuitive insights that arise from researchers' earlier exposure to their data (as they interviewed informants, read and coded archival documents and transcripts, observed interactions, etc.). These intuitive insights can be extremely valuable to grasp important patterns in the data. However, they can also, on occasion, be misleading, as researchers may unconsciously pay disproportionate attention to vivid evidence or the words of more eloquent or charismatic informants. Or they can involuntarily reflect preconceived assumptions, effectively leading a researcher to focus attention on evidence that seems to confirm prior, possibly unarticulated, expectations. An important use of concept-evidence tables is therefore to help researchers address these issues by forcing them to systematically track the extent to which each element of their emerging theoretical framework is really supported by available evidence.

When doing so, analytical work can also be supported by coding schemes - tables dedicated to keeping track of a study's codes-in-use and their relevant descriptions, as they develop (see Goh and Pentland, 2019, Table 2, for an example of a final, polished examples, used for communication purposes). Coding schemes not only provide clarity to criteria used to classify and interpret empirical observations, but also help set the stage for a rigorous in-depth analysis of the data, and they are usually expanded, revised and finetuned as analysis progresses. They increase confidence in the reliability (Yin, 2003) and dependability (Lincoln and Guba, 1985) of researchers' conclusions by reassuring that the 
coding of evidence was based on clearly stipulated criteria, rather than loose or intuitive ones, and by establishing clear terms for an independent review of analytical procedures and assessment of available evidence.

Concept-evidence tables and coding schemes more generally increase trustworthiness in the quality of the analysis by reassuring readers that researchers made a conscious, systematic engagement with their data to establish solid empirical support for their emerging interpretations ${ }^{2}$. In addition, they expand the capacity to "show" (Golden-Biddle \& Locke, 2007) illustrative evidence supporting one's claims - often advocated as essential to build trustworthiness (Pratt et al., 2020) - without burdening excessively the narration of one's findings.

A similar function is performed by cross-case comparative tables, generally used in multiple-case studies to highlight similarities or differences by gathering and ordering evidence by concept and by case. In management research, cases often correspond to the unit of analysis of a study: organizations, teams, projects, or - albeit more rarely individuals. This type of table operates by contrasting cases along one or more aspects, gathering data from multiple sources into a single display to facilitate comparison across cases to highlight similarities or differences, to triangulate across sources (to ascertain robustness), and/or to identify possible patterns through the sorting and listing of cases along multiple criteria (to detect associations in constructs that vary by a degree). They can be used to support analyses aimed at producing variance theories (e.g. Eisenhardt, 1989a),

\footnotetext{
${ }^{2}$ While conceptually distinct, concept-evidence tables and coding schemes perform a similar function in supporting a conscious, systematic effort to code. In fact, in our own research, we tend to use working tables that both gather evidence for concepts and include tentative definitions for these concepts (we usually do this only for more analytical, second-order codes). Doing so facilitates an ongoing check of face validity and content validity - to borrow expressions from positivistic criteria for research evaluation - by juxtaposing provisional labels and definitions and the evidence we gradually cumulate, helping to ensure that our interpretations, reflected in analytical codes, match and adequately cover available evidence.
} 
process theories (e.g. Kaplan and Orlikowski, 2013) or a combination of both (e.g. Cloutier and Ravasi, 2020).

When used to account for variance across cases, for example, these tables will often list cases in the first column, their order reflecting variation in the construct to be explained (e.g. the "dependent" variable, such as high vs. low velocity in decision making in Eisenhardt, (1989b, see Table 2). Evidence for this variation can then be included in the second column of the same table, or in a separate concept-evidence table. The adjoining columns can then be used to display evidence from one or more sources for a second construct, whose association with the first construct is being explored in the table. Used in this way, these tables increase trustworthiness in the generalizability of theoretical claims derived from cross-case comparisons by accounting for the "replication logic" that underlie these claims (Eisenhardt, 1989a; Yin, 2003).

Alternatively, cross-case comparative tables can also be used to explore similarities and differences across cases in how a process unfolds. In this variation, cases are listed in the first column, and evidence of a given construct at different points of time are provided in the adjoining columns. When used this way, cross-case comparative tables can help organize and compare cases along the same set of analytical categories (and by so doing, help spot gaps in these analyses). The analytical categories informing such comparative analyses can then be used as building blocks for the emerging process model. Used in this way, these tables help move cross-case analysis of empirical observations to a higher level of abstraction, by showing robust support for an overarching theoretical framework (reflecting similarities across cases) or by grouping cases (based on intra-group similarities 
and inter-group differences) to highlight patterns in how the focal process or processes vary.

A particular variant of cross-case comparative tables, which we refer to as cooccurrence tables, can be useful to examine whether and how (or, sometimes, how frequently) different features of cases tend to co-occur, by ordering them in a way that visually reveals patterns in the distribution of these features. Cells in these tables will often contain processed data, in the form of symbols, tick marks, frequency counts, or summary qualitative descriptions of observations (see for instance, Grimes, (2018, Table 2) because the primary purpose of these tables is to explore the distribution of certain features among cases. In this respect, these tables can be considered the visual equivalent of a correlation table for quantitative researchers.

Co-occurrence tables can be particularly useful when the number of cases is high (rendering more extensive display and manipulation of evidence in cells impractical) and the intent is not to search for differences between two "polar" groups of cases (as in Eisenhardt, 1989b), but rather to cluster cases based on similar properties or behaviors (dependent variables). The aim is to hopefully identify other properties that co-occur with (and can possibly explain) the focal ones by searching for similarities in the structural or temporal features of cases that tend to behave similarly. Co-occurrence tables, then, may be particularly useful at later stages in the analysis, after deeper immersion in the data has drawn attention to core constructs (e.g. key decisions, behaviors, structures, cognitions, etc.), to explore patterns in the manifestation of these constructs in one's database. For example, McPherson and Sauder (2013, see Tables 2, 3, and 4) used this type of table in their study of negotiations in a drug court to track the number of times each type of actor 
invoked a particular institutional logic, and whether such invocations were successful or not (in changing the severity of sanctions the court imposed on defendants), again, by type of actor; doing this helped reveal patterns in who invoked what logics more or less successfully across cases.

What goes into the cells of a co-occurrence table need not be only numbers: in some cases, authors use check marks to signal whether a given property of a concept was observed across cases. Examples of this sort of use include Pache and Santos (2013, Table 6) and Compagni, Mele and Ravasi (2015, Table 6). By doing so, co-occurrence tables increase trustworthiness in the analysis by transparently disclosing evidence for claims of systematic association among observations, notably when qualitative data are used to support variance theories.

Temporally-ordered tables - which Miles and Huberman (1984) also refer to as or timeordered tables - help track events or changes in a unit of analysis or a concept over time. By ordering data by time and sequence, they allow researchers to examine what happened when and what might have led to what (Miles and Huberman, 1994), or compare changes in empirical observations over time. They are particularly useful, if not indispensable, to understand processes (Langley, 1999). Choosing what to document across rows or columns allows researchers to compare units of analysis (actors, organizations, activities, etc.) or concepts across time, to document whether they appear or not at different points in time, or whether and how they manifest any changes over time.

Temporally-order tables can take many forms. An important and useful distinction to make between them is that they can be organized by "clock time" or "epochal time" (Mosakowski and Earley, 2000). Tables organized by clock time track changes in a unit 
of analysis or a concept as it unfolds over days, months, or years. These tables are particularly useful to identify temporal patterns, such as sequences, progressions or cycles in the early stages of analysis, as they help order observations chronologically. They make it possible, for instance, to track the ebb and flow of activities over time, and to note periods of "dead" time when no activities have taken place, all of which could be significant from an analytical or theoretical standpoint. For an example of a temporallyordered table organized by clock time see Michel (2011, Table 3).

Tables organized by epochal time, instead, organize observations around conceptually distinct phases that capture qualitative changes in focal concepts or their features.

Transition points from one temporal block to the next are not marked by elapsed time but by criteria that reflects time as it is perceived by informants or the theoretical interests of the analyst. The early and tentative bracketing of time (Langley, 1999) that characterizes these tables often results from intuitive observations pointing to temporal variation in relevant constructs, which these tables help analyze more consciously and systematically. Epochal timetables are particularly useful for identifying the phases or stages of a process, and the changes in focal concepts that underpin that process. For an example of a temporally-ordered table organized by epochal time, see Zietsma and Lawrence (2010,

\section{Table 2).}

Each time block, whether on clock time or epochal time, could be as long or as short as the context and the researcher chooses, allowing for a more fine-grained, micro-analysis of activities, events, or states over time, or conversely, a longer-term, macro view of the same - the equivalent of zooming in or zooming out when examining time-related phenomena when studying processes (Cloutier and Langley, 2020). In our own study of identity 
trajectories, we used several temporally-ordered tables to construct and validate the trajectories followed by the identities of four organizations over several decades (the Online Appendix offers a behind-the-scenes account of of how we constructed and used these tables).

Whereas temporally-ordered tables are useful to identify temporal patterns, typologically-ordered tables are used to compare different manifestations or properties of a concept (e.g. different types of process, practice, strategy, structure, belief, etc.) across a study's whole database, in order to highlight similarities and differences in empirical observations. Their cells rarely contain evidence. If they do, it tends to be minimal and associated with a descriptive or theoretical labelling of observations that helps flesh out the similarities and differences between them. Typologically-ordered tables have been used extensively, for instance, to present clearly and succinctly different institutional logics in play in a particular setting (see for example Pache and Santos, 2013, Table 3).

The identification of the relevant types to include in a table often follows a more holistic, intuitive engagement with one's data that highlights possible patterns that a typologicallyordered table helps examine more systematically. Sometimes, informants themselves point at variation in beliefs or practices, for example, that the use of these tables helps articulate typologically. Other times, the relevant types may emerge from a prior step in the analysis: in these cases, typologically-ordered tables may help explore similarities and differences between properties other than those that initially led to the tentative grouping.

Typologically-ordered tables, in this respect, support analytical efforts in at least two ways. First, these tables can be used to articulate typological differences by bringing together the outcome of prior comparative analyses. Typologically-ordered tables, in this 
respect, may be used to connect different findings to reveal a bigger picture (that is, the existence of typological patterns that help explain the observed variation in the data), and - when submitting a paper - may be coupled with concept-evidence tables or cross-case comparative tables to establish the empirical grounding of the claimed typological differences.

Alternatively, these tables can be used to support a more immersive engagement with the data - such as found in ethnographic research - without necessarily relying on prior systematic coding and table-making but using a tabular form to structure the interpretation of typological patterns in a rich qualitative database. While researchers may intuitively grasp the presence of such patterns - or be alerted to them by informants - they may initially have only a fragmented understanding of the features that characterize each type. Typologically-ordered tables, in this respect, can help researchers flesh out different types, by forcing them to articulate typological differences along a common set of features.

In term of trustworthiness, temporally-ordered tables and typologically-ordered tables perform similar functions in that, during the analysis, they both support the systematic tracking of empirical support for apparent patterns (temporal or typological). Later, they can be used to facilitate independent assessment of the extent to which claimed patterns are actually reflected in empirical evidence. While a similar function may indeed be performed by exemplification in the main text, this type of tables enables a concise summary of core observations, effectively bridging "theory narrative" and "data narrative" (Bansal and Corley, 2012).

Finally, but no less importantly, tables can be used to support the articulation of the fundamental elements of an emerging theoretical account. We refer to this type of table as 
a theoretical summary. The cells of this table do not contain reference to empirical observations, but rather to theoretical definitions and/or explanations. Theoretical summaries help researchers "think through" their interpretations, by adding depth to their understanding of the concepts that appear important to explain what is going on in a study, and how they are related. In this respect, they are particularly useful to support the "creative leap" (Langley \& Klag, 2013) from empirical observation to theoretical explanation, especially when facing complex models that need to simultaneously illustrate and account for variation across units of analysis.

In principle, the structure of theoretical summaries can mirror the structure of any of the analytical tables we described previously - it simply replaces empirical content (evidence in raw or processed form) with theoretical content (labels and/or explanations). Theoretical summaries, in this respect, can help researchers theorize their findings, should they opt for an approach to qualitative research that invites them to distinguish empirical observations from They do so by structuring and outlining the conceptual space (concepts, phases, conditions, etc.) that need to be accounted for by this theorization, thus helping ensure a thorough explanation of empirical observations (as cells are gradually filled with theoretical content). In fact, the content of this table can often be transferred and rearranged in the main text to form an initial draft of the section illustrating the emerging theoretical framework.

This type of table can be particularly useful to track and explain variation in how a process unfolds across different cases or under different conditions (a rare case of a theory that is simultaneously variance and process). In our own study of long-term patterns of identity change, we used a theoretical summary to support the integration of empirical 
observations across cases into an overall theoretical framework (Cloutier and Ravasi, 2020). By assigning rows to different elements of the process model and columns to different types of processes, we could use the table to simultaneously assist us in the theorization of how different elements of the model worked together to explain the change patterns we observed (process analysis) and how these elements differed across groups of cases, leading to different types of processes (cross-case analysis).

From an analytical perspective, concept-evidence, cross-case analysis, co-occurrence, temporally-ordered, typologically-ordered and theoretical summary tables contribute to enhance trustworthiness by supporting more conscious mental processes aimed at uncovering and making sense of patterns in the data. In particular, they do so by helping researchers contrast \& compare data (useful especially for variance-oriented theory), track progression \& sequences (for process-oriented theory), reveal co-occurrence (variance theory), and gauge completeness of theorization. By ensuring the presence of robust evidence for each claimed pattern, these tables support the dependability and confirmability of emerging interpretations. In other words, they ensure that researchers can respond positively to the question: "Do I have the data to claim what I think I know about my setting?"

When producing tables geared for analysis, authors should keep track of the various decisions they made in association with a specific table (such as which criteria they used to condense data, classify observations, etc.) and describe in detail the theoretical reflections that the table stimulates. Such decisions and descriptions should be attached to each table, and in the case of complex and protracted analyses, there may be some benefit in keeping track of these decisions in a separate table, so as to facilitate the reproduction 
of the study's "audit trail" which is an important way of ensuring reliability and confirmability of qualitative research findings (Lincoln and Guba, 1985).

Another good habit is to keep track of data sources when entering data into cells (e.g. who the informant was, which document is quoted, when field notes were taken, etc.). Copy and paste functions make it all too easy to quickly fill table cells without systematically making note of where an excerpt or quote came from. Retracing sources after the fact can quickly become a nightmare and compromise the integrity of the research process. In this regard, it helps to develop a coding system that allows researchers to identify sources easily without occupying too much space in a cell.

Finally, when using analytical tables to highlight patterns, it can be helpful to find creative ways - using symbols and other methods - to reduce large tables (especially those that contain all the evidence in support of a concept which can extend over dozens of pages) to a single page, even if it is a very big page that is posted on a wall (Miles and Huberman, 1994), because the distribution of a table over multiple pages may make it more difficult to discern patterns in its content.

\section{Displaying}

Once analysis is complete and researchers are confident that they have come to some interesting or meaningful insight, tables become useful to present findings in a clear, parsimonious and convincing way. A well-designed table will not only synthesize evidence in support of an author's claims, it will also allow readers to see - at a glance - the connections an author is trying to make between different concepts, observations, or pieces of evidence that he or she has identified as important.

The primary purpose of display tables then is to communicate a study's findings to an unknowing, often skeptical, and possibly novice (at least as far as the specific empirical 
context of a study is concerned) audience. Persuading this audience requires scholars to adapt analytical tables - which are often lengthy, dense, and quite detailed - in ways that preserve richness and comprehensiveness (from a data display perspective), while at the same time renders them aesthetically appealing (to the extent possible within editorial guidelines) and intuitively easy to understand. To achieve this, scholars need to think about how the human brain processes visual information (for example, objects that are close together, similar or connected are almost always perceived as belonging to a group; see (Cairo, 2012), and use the design tools at their disposal (white space, font sizes and types, borders and colour) to transform their possibly clunky analytical tables into appealing and convincing "snapshots" of their data (Few, 2012).

Well-designed display tables help researchers concretely show how they got "from 3600 pages of field notes to their final conclusions" (Miles and Huberman, 1994) and avoid the criticism - often directed at qualitative scholars - that they are merely cherry-picking quotes in support of their claims. Qualitative researchers have been repeatedly encouraged to "show" rather than "tell" readers about their data (Golden-Biddle and Locke, 2007, Pratt, 2009, Pratt et al., 2020b), and reviewers and editors often lament the lack of data in the manuscripts they assess (Pratt, 2008). Overwhelming readers with quotes and observational facts is not a solution however, as doing so may drown out a compelling analysis (ibid). Striking the right balance between "showing" and "telling" can therefore be tricky. While there are many ways researchers can do this, such as using vignettes, extensive excerpts, or detailed narratives (Reay et al., 2019), one of the most common ways is to use "power quotes" to support arguments in the main body of a text and to back these with supplementary "proof quotes" (Pratt, 2008) in a separate table. 
Finally, while complex, multi-functional tables are occasionally seen in published work, in our view it is generally not a good idea to ask a display table to do too many things at once. Trying to include too much information in a single table - for instance, by using the same table to display robust support for a set of constructs AND at the same time show the co-occurrence of these constructs across multiple cases, or show multiple patterns at the same time - often results in complex, unwieldy, unreadable or confusing tables. This problem can be avoided by drawing separate tables, with each of them performing only one function. While this may result in the proliferation of tables in a paper, at least it makes it clear what the purpose of each table is, what type of information it intends to convey, and what patterns it intends to highlight. Conversely, trying to convey too much information within a single table may end up obscuring important patterns (for an example of such table, see Table 2 in Rindova, Dalpiaz \& Ravasi (Rindova et al., 2011) $)^{3}$ ).

In this respect, it may be worth spending some time, when writing a paper, reflecting on a "table plan": what tables could I use to show empirical support for the concepts that constitute my emerging theoretical explanation for what I observed? What tables could I use to show support for the (temporal, typological, correlational, etc.) patterns that I observed? Could a table help me illustrate how I transitioned from empirical observations to theoretical arguments, or summarize more clearly the latter? Even if these tables never become part of the paper, reflecting on them may offer authors another opportunity to think through their interpretations before sending a paper out.

\footnotetext{
${ }^{3}$ This table results from the merger of three separate tables - for the sake of space saving - initially built to gather evidence of cultural resources incorporated in the repertoire of the organization over time, to link new practices to the cultural resources that inspired them, and to show temporal progressions of these events, respectively; none of these messages is clearly conveyed by the resulting table (see Ravasi, Rindova, and Dalpiaz, 2017, for an illustration of the working tables used during the analysis).
} 


\section{Conclusions}

In the previous paragraphs we discussed the three main uses of tables in qualitative research - organizing, analyzing and displaying - and presented examples of different types of tables as an inspiration for scholars interested in adding tables to their qualitative methods toolbox. We've argued that tables are practical for organizing and keeping track of qualitative data; efficient for sorting data in a way that facilitates comparisons and the noticing of patterns; and effective at presenting findings in a clear and convincing way. It is no wonder then that Miles and Huberman's central argument in the book that set the trend for using of tables in qualitative research is: "you know what you display" (Miles and Huberman, 1994).

Figure 4 summarizes the different functions of tables as they might be used throughout the research process. In Table 3, we summarize the ways in which each type of table enhances trustworthiness in the research process itself - that is, confidence that the researcher has followed rigorous procedures to collect and analyze data (see Rheinhardt, Gioia \& Kreiner, 2017) and presented them in an "honest" and transparent way (Pratt et al., 2020) - and trustworthiness in a study's conclusions - that is confidence that the researcher's interpretations are "reasonable" (Pratt et al., 2020), plausible and grounded in robust empirical evidence.

\section{INSERT TABLES 3 ABOUT HERE}

In closing, we wish to leave readers with two additional thoughts. First, the generic table types presented here should be viewed as tools, not templates. The examples presented are not meant to illustrate a set of rules for how tables should be drawn, but rather to reflect the myriad ways that researchers have used tables in both published and unpublished work. Each table type should therefore be viewed as a blank canvas that individual researchers 
can populate as they see fit, with the examples provided serving only as inspiration for those less familiar with the wide range of ways in which tables can be used throughout the various stages of any qualitative research process.

Second, despite their versatility and various uses, authors must remember that tables are not meant to be stand-alone entities, they need to be referenced, narrated and explained in the body of an article. Miles and Huberman refer to this as the "analytic text" that accompanies a table (1994). As such, tables should not be conceived as mere repositories of information - or quotes - to be included out of conformity to a presumed template. Tables offer a great opportunity to include, in a concise way, important information that might otherwise unnecessarily lengthen a paper, but that can be usefully referenced from the main text. For instance, concept-evidence tables can be referred to as additional supportive evidence or provide a more detailed illustration of observations summarized in main text. Cross-case tables can be referenced to point to similar patterns in other cases than those described more extensively in the main text. And event lists or temporallyordered tables can be referenced in place of lengthy descriptions of event sequences.

Tables should really be thought of as complementing - rather duplicating - the content of the main text. When using data source tables, for instance, the description of data collection can focus on the process, rather than the sources. Similarly, the inclusion of a coding scheme or a data analysis table may lighten up the description of data analysis. Theoretical summaries can be used to illustrate at a glance - and therefore help readers grasp - theoretical arguments presented in more detail over multiple pages. Indeed, we think of tables - or table-making - as complementary to theory development itself. As useful as they may be, tables per se cannot be a replacement for carefully and convincingly 
crafted arguments. Yet, by helping researchers engage more consciously and visually with their data as well as their emerging interpretations, tables may be crucial in the development of these arguments. After all, as E.M. Forster is supposed to have said: "How can I tell what I think till I see what I say?" 


\section{REFERENCES}

ASTLEY, W. G. 1985. Administrative Science as Socially Constructed Truth. Administrative Science Quarterly, 30, 497-513.

AUGUSTINE, G., SODERSTROM, S., MILNER, D. \& WEBER, K. 2019. Constructing a Distant Future: Imaginaries in Geoengineering. Academy of Management journal, 62, 1930-1960.

BANSAL, P. \& CORLEY, K. 2012. Publising in AMJ - Part 7: What is different about qualitative research? Academy of Management Journal, 55, 509-513.

BECHKY, B. A. \& OKHUYSEN, G. A. 2011. Expecting the unexpected? How SWAT officers and film crews handle suprises. The Academy of Management Journal, 54, 239-261.

BORÉUS, K. \& BERGSTRÖM, G. 2017. Analyzing Text and Discourse: Eight Approaches for the Social Sciences.

BOTHELLO, J. \& SALLES-DJELIC, M. L. 2018. Evolving Conceptualizations of Organizational Environmentalism: A Path Generation Account. Organization Studies, 39, 93-119.

CAIRO, A. 2012. The Functional Art: An Introduction to Information Graphics and Visualization, San Francisco: CA, Pearson Education.

CAMOES, J. 2016. Data at Work: Best Practices for Creating Effective Charts and Information Graphics in Microsoft Excel, San Francisco: CA, Pearson Education.

CANATO, A., RAVASI, D. \& PHILLIPS, N. 2013. Coerced practice implementation in cases of low cultural fit: Cultural change and practice adaptation during implementation of Six Sigma at 3M. The Academy of Management Journal, 56, 1724-1753.

CHARMAZ, K. 2006. Constructing Grounded Theory: A Practical Guide Through Qualitative Analysis, London, Uk, Sage.

CHRISTIANSON, M. K. 2019. More and Less Effective Updating: The Role of Trajectory Management in Making Sense Again. Los Angeles, CA: SAGE Publications.

CLOUTIER, C. \& LANGLEY, A. 2020. What makes a process theoretical contribution? Organization Theory, $1,1$.

CLOUTIER, C. \& RAVASI, D. 2020. Identity Trajectories: Explaining Long-Term Patterns of Continuity and Change in Organizational Identities. Academy of Management Journal, 63, 1196-1235.

COHEN, S. L., BINGHAM, C. B. \& HALLEN, B. L. 2019. The Role of Accelerator Designs in Mitigating Bounded Rationality in New Ventures. Administrative Science Quarterly, 64, 810-854.

COMPAGNI, A., MELE, V. \& RAVASI, D. 2015. How Early Implementations Influence Later Adoptions of Innovation: Social Positioning and Skill Reproduction in the Diffusion of Robotic Surgery. Academy of Management Journal, 58, 242-278.

COZZOLINO, A., VERONA, G. \& ROTHAERMEL, F. T. 2018. Unpacking the Disruption Process: New Technology, Business Models, and Incumbent Adaptation. Journal of Management Studies, 55, 1166-1202. 
CROIDIEU, G. \& KIM, P. H. 2018. Labor of Love: Amateurs and Lay-expertise Legitimation in the Early U.S. Radio Field. Administrative science quarterly, 63, $1-42$.

DALPIAZ, E., RINDOVA, V. \& RAVASI, D. 2016. Combining Logics to Transform Organizational Agency: Blending Industry and Art at Alessi. Administrative Science Quarterly, 61, 347-392.

EISENHARDT, K. M. 1989a. Building theories from case study research. Academy of Management Review, 14, 532-550.

EISENHARDT, K. M. 1989b. Making fast strategic decisions in high-velocity environments. Academy of Management Journal, 32, 543-576.

FARNY, S., KIBLER, E. \& DOWN, S. 2019. Collective Emotions in Institutional Creation Work. Academy of Management Journal, 62, 765-799.

FELDMAN, M. 1995. Strategies for Interpreting Qualitative Data, Thousand Oaks, CA, Sage.

FEW, S. 2012. Show Me the Numbers: Designing Tables and Graphs to Enlighten, Burlingame, CA, Analytics Press.

GEPHART, R. P. 2004. Qualitative Research and the Academy of Management Journal. Academy of Management Journal, 47, 454-462.

GIOIA, D. A., CORLEY, K. G. \& HAMILTON, A. L. 2013. Seeking Qualitative Rigor in Inductive Research: Notes on the Gioia Methodology. Organizational Research Methods, 16, 15-31.

GLESNE, C. 1999. Becoming Qualitative Researchers: An Introduction, New York: NY, Longman.

GOH, K. T. \& PENTLAND, B. T. 2019. From Actions to Paths to Patterning: Toward a Dynamic Theory of Patterning in Routines. Academy of Management Journal, 62, 1901-1929.

GOLDEN-BIDDLE, K. \& LOCKE, K. 2007. Composing Qualitative Research, Thousand Oaks, CA, Sage.

GRIMES, M. G. 2018. The Pivot: How Founders Respond to Feedback through Idea and Identity Work. Academy of Management Journal, 61, 1692-1717.

GRODAL, S. 2018. Field expansion and contraction: How communities shape social and symbolic boundaries. Administrative Science Quarterly, 63, 783-818.

GRODAL, S., ANTEBY, M. \& HOLM, A. L. 2020. Achieving Rigor in Qualitative Analysis: The Role of Active Categorization in Theory Building. Academy of Management Review.

HEHENBERGER, L., MAIR, J. \& METZ, A. 2019. The assembly of a field ideology: An idea-centric perspective on systemic power in impact investing. Academy of Management Journal, 62.

HOPPMANN, J., NAEGELE, F. \& GIROD, B. 2019. Boards as a source of inertia:

Examining the internal challenges and dynamics of boards of directors in times of environmental discontinuities. Academy of Management Journal, 62, 437-468.

HOWARD-GRENVILLE, J., METZGER, M. L. \& MEYER, A. D. 2013. Rekindling the flame: processes of identity resurrection. Academy of Management Journal, 56, 113. 
JARZABKOWSKI, P., BEDNAREK, R. \& L, J. K. 2014. Producing persuasive findings: Demystifying ethnographic textwork in strategy and organization research. Strategic Organization, 12, 274-287.

JARZABKOWSKI, P., LE, J. \& BALOGUN, J. 2019. The Social Practice of Coevolving Strategy and Structure to Realize Mandated Radical Change. Academy of Management Journal, 62, 850-882.

JONSEN, K., FENDT, J. \& POINT, S. 2018. Convincing Qualitative Research: What Constitutes Persuasive Writing? Organizational Research Methods, 21, 30-67.

KAPLAN, S. \& ORLIKOWSKI, W. J. 2013. Temporal work in strategy making. Organization Science, 24, 956.

KELLOGG, K. C. 2019. Subordinate Activation Tactics: Semi-professionals and Microlevel Institutional Change in Professional Organizations. Administrative Science Quarterly, 64, 928-975.

KREINER, G. E., HOLLENSBE, E., SHEEP, M. L., SMITH, B. R. \& KATARIA, N. 2015. Elasticity and the dialectic tensions of organizational identity: how can we hold together while we are pulling apart? Academy of Management Journal, 58, 981-1011.

KROEZEN, J. J. \& HEUGENS, P. P. M. A. R. 2019. What Is Dead May Never Die: Institutional Regeneration through Logic Reemergence in Dutch Beer Brewing. Administrative Science Quarterly, 64, 976-1019.

LANGLEY, A. 1999. Strategies for theorizing from process data. Academy of Management Review, 24, 691-710.

LINCOLN, Y. S. \& GUBA, E. G. 1985. Establishing trustworthiness. Naturalistic Inquiry. Newbury Park, CA: SAGE Publications.

LOCKE, K. 2001. Grounded Theory in Management Research, London, Uk, Sage.

MARTIN, J. A. \& EISENHARDT, K. M. 2010. Rewiring: Cross-business-unit collaborations in multibusiness organizations. Academy of Management.

MASON, J. 2002. Qualitative Researching, Sage Publications, London: UK.

MCPHERSON, C. M. \& SAUDER, M. 2013. Logics in action: Managing institutional complexity in a drug court. Administrative Science Quarterly, 58, 165-196.

MICHEL, A. 2011. Transcending Socialization: A Nine-Year Ethnography of the Body's Role in Organizational Control and Knowledge Workers' Transformation. Administrative Science Quarterly, 56, 325-368.

MILES, M. B. \& HUBERMAN, A. M. 1994. Qualitative Data Analysis, Thoursand Oaks, CA, Sage.

MILES, M. B., HUBERMAN, M. \& SALDANA, J. 2020. Qualitative Data Analysis: A Methods Sourcebook, Thousand Oaks: CA, Sage.

MOHR, L. B. 1982. Explaning Organizational Behavior, San Francisco: CA, JosseyBass.

MOSAKOWSKI, E. \& EARLEY, P. C. 2000. A Selective Review of Time Assumptions in Strategy Research. The Academy of Management Review, 25, 796-812.

NADIN, S. \& CASSELL, C. 2004. Using data matrices. In: CASSELL, C. \& SYMON, G. (eds.) Essential Guide to Qualitative Methods in Organizational Research. London: UK: Sage.

NIGAM, A. \& DOKKO, G. 2019. Career resourcing and the process of professional emergence. Academy of Management Journal, 62, 1052-1084. 
O'MAHONEY, J., HEUSINKVELD, S. \& WRIGHT, C. 2013. Commodifying the Commodifiers: The Impact of Procurement on Management Knowledge. Journal of Management Studies, 50, 204-235.

PACHE, A.-C. \& SANTOS, F. 2013. Inside the hybrid organization: Selective coupling as a response to competing institutional logics. Academy of Management Journal, $56,972-1001$.

PANDZA, K. 2011. Why and How Will a Group Act Autonomously to Make an Impact on the Development of Organizational Capabilities? Journal of Management Studies, 48, 1015-1043.

PATTON, M. Q. 2003. Qualitative Research and Evaluation Methods, Thousand Oaks, CA, Sage.

PRATT, M. 2009. For the lack of a boilerplate: Tips on writing up (and reviewing) qualitative research. Academy of Management Journal, 52, 856.

PRATT, M. G. 2008. Fitting Oval Pegs Into Round Holes: Tensions in Evaluating and Publishing Qualitative Research in Top-Tier North American Journals.

Organizational Research Methods, 11, 481-509.

PRATT, M. G., KAPLAN, S. \& WHITTINGTON, R. 2020a. Editorial Essay: The Tumult over Transparency: Decoupling Transparency from Replication in Establishing Trustworthy Qualitative Research. Administrative science quarterly, $65,1-19$.

PRATT, M. G., SONENSHEIN, S. \& FELDMAN, M. S. 2020b. Moving Beyond Templates: A Bricolage Approach to Conducting Trustworthy Qualitative Research. Organizational Research Methods.

RAVASI, D., RINDOVA, V. \& STIGLIANI, I. 2019. The Stuff of Legend: History, Memory, and the Temporality of Organizational Identity Construction. Academy of Management Journal, 62, 1523-1555.

RAVASI, D., RINDOVA, V. \& DALPIAZ, E. (2017). Analyzing changes in organizational cultural repertoires. The Routledge Companion to Qualitative Methods in Organization Studies. R. Mir and S. Jain. London, UK, Routledge: 203-225.

REAY, T., ZAFAR, A., MONTEIRO, P. \& GLASER, V. L. 2019. Presenting findings from qualitative research: One size does not fit all! In: ZILBER, T. B., AMIS, J. \& MAIR, J. (eds.) Research in the Sociology of Organizations. Bingley, UK: Emerald Publishing Ltd.

RINDOVA, V., DALPIAZ, E. \& RAVASI, D. 2011. A cultural quest: A study of organizational use of new cultural resources in strategy formation. Organization Science, 22, 413-431.

SADEH, L. J. \& ZILDER, T. B. 2019. Bringing "Together": Emotions and Power in Organizational Responses to Institutional Complexity. Academy of Management Journal, 62, 1413-1443.

SALDANA, J. 2016. The Coding Manual for Qualitative Researchers, Thousand Oaks: CA, Sage.

SMITH, A. N., WATKINS, M. B., LADGE, J. J. \& CARLTON, P. 2019. Making the invisible visible: Paradoxical effects of intersectional invisibility on the career experiences of executive black women. Academy of Management Journal, 62, 1705-1734. 
SMITH, W. K. 2014. Dynamic decision making: A model of senior leaders managing strategic paradoxes. Academy of Management Journal, 57, 1592-1623.

SPRADLEY, J. P. 1979. The Ethnographic Interview, New York, NY, Holt, Rinehart and Winston.

SPRADLEY, J. P. 1980. Participant Observation, New York, NY, Holt, Rinehart and Winston.

SUTTON, R. I. \& HARGADON, A. 1996. Brainstorming Groups in Context: Effectiveness in a Product Design Firm. Thousand Oaks: Cornell University Samuel Curtis Johnson Graduate School of Management.

WEICK, K. E. 1995. Sensemaking in Organizations, Thousand Oaks: CA, Sage.

YIN, R. K. 2003. Case Study Research, Thousand Oaks, CA, Sage.

ZIETSMA, C. \& LAWRENCE, T. B. 2010. Institutional Work in the Transformation of an Organizational Field: The Interplay of Boundary Work and Practice Work. Administrative Science Quarterly, 55, 189-221.

ZILBER, T. 2011. Institutional multiplicity in practice: A tale of two high-tech conferences in Israel. Organization Science, 22, 1539-1559.

ZIMMERMANN, A., RAISCH, S. \& CARDINAL, L. B. 2018. Managing Persistent Tensions on the Frontline: A Configurational Perspective on Ambidexterity: Managing Persistent Tensions on the Frontline. Journal of Management Studies, 55, 739-769. 


\begin{tabular}{|c|c|c|c|c|}
\hline Type & Simple version & Variations & Where? & Examples \\
\hline Data inventory & $\begin{array}{l}\text { List of all data items collected for a } \\
\text { study }\end{array}$ & + descriptive features & Not usually published & \\
\hline $\begin{array}{l}\text { Data sources } \\
\text { table }\end{array}$ & $\begin{array}{l}\text { List of data sources by type } \\
\text { (description and quantity) }\end{array}$ & $\begin{array}{l}\text { + use in analysis } \\
+ \text { breakdown by time } \\
+ \text { contribution to findings }\end{array}$ & Method & $\begin{array}{l}\text { Jarzabkowski, Lê and Balogun (2019, Table 1) } \\
\text { Farny, Kibler and Down (2019, Table 1) } \\
\text { Howard-Grenville, Metzger and Meyer (2013, Table 1) }\end{array}$ \\
\hline $\begin{array}{l}\text { Data analysis } \\
\text { table }\end{array}$ & $\begin{array}{l}\text { List of analytical steps followed } \\
\text { (description) }\end{array}$ & $\begin{array}{l}+ \text { selected examples (of how } \\
\text { analysis was done) } \\
+ \text { description of outcomes }\end{array}$ & Method & $\begin{array}{l}\text { Smith (2014, Table 3) } \\
\text { O’Mahoney, Heusinkveld and Wright (2013, see Table 3) }\end{array}$ \\
\hline Case summary & $\begin{array}{l}\text { List of cases and their most } \\
\text { relevant features }\end{array}$ & + selected evidence & Method & $\begin{array}{l}\text { Martin and Eisenhardt (2010, Table 1) } \\
\text { Hehenberger, Mair and Metz (2019, Table 1) } \\
\text { Hoppman, Naegele and Girod (2019, Table 1) }\end{array}$ \\
\hline Event listing & $\begin{array}{l}\text { Chronological list of events, } \\
\text { activities, milestones, etc. } \\
\text { (description) }\end{array}$ & + selected evidence & Method, findings & $\begin{array}{l}\text { Zietsma and Lawrence (2010, Table 1) } \\
\text { Bothello and Salles-Djelic (2018, Table 1) }\end{array}$ \\
\hline $\begin{array}{l}\text { Concept- } \\
\text { evidence table }\end{array}$ & $\begin{array}{l}\text { List of concepts with selected } \\
\text { evidence }\end{array}$ & $\begin{array}{l}\text { + description (of each } \\
\text { concept) } \\
\text { + properties (of each concept) } \\
\text { + triangulated evidence }\end{array}$ & Method, findings & $\begin{array}{l}\text { Kreiner (2015, Table 3) } \\
\text { Farny, Kibler and Down (2019, Tables 2a, 2b and 2c) } \\
\text { Sutton and Hargadon (1996, Table 1) (using multiple data sources) }\end{array}$ \\
\hline Coding scheme & List of codes and their description & + selected evidence & Findings & $\begin{array}{l}\text { Christianson (2019, Table } 1) \\
\text { Smith, Watkins, Ladge and Carlton (2019, Table 1) }\end{array}$ \\
\hline $\begin{array}{l}\text { Cross-case } \\
\text { analysis table }\end{array}$ & $\begin{array}{l}\text { Comparison of concepts by case } \\
\text { with selected evidence }\end{array}$ & $\begin{array}{l}\text { + properties (of each concept) } \\
+ \text { triangulated evidence }\end{array}$ & Method, findings & $\begin{array}{l}\text { Eisenhardt (1989b, Table 4) } \\
\text { Cohen, Bingham and Hallen (2019, Tables } 2 \text { and 3) }\end{array}$ \\
\hline $\begin{array}{l}\text { Co-occurrence } \\
\text { table }\end{array}$ & $\begin{array}{l}\text { Comparison of co-occurrence of } \\
\text { features or concepts across cases }\end{array}$ & $\begin{array}{l}+ \text { assessment of frequency } \\
+ \text { co-occurrence across time }\end{array}$ & Findings & $\begin{array}{l}\text { McPherson and Sauder (2013, Tables } 2 \text { and 3) } \\
\text { Compagni, Mele and Ravasi (2015, Table 6) }\end{array}$ \\
\hline $\begin{array}{l}\text { Temporally- } \\
\text { ordered table }\end{array}$ & $\begin{array}{l}\text { Temporal comparison of concepts } \\
\text { or events with selected evidence }\end{array}$ & + properties (of each concept) & Findings & $\begin{array}{l}\text { Michel (2011, Table 3) (clock time) } \\
\text { Canato, Ravasi and Phillips (2013, Table 3) (epochal time) } \\
\text { Zietsma and Lawrence (2010, Table 2) (epochal time) }\end{array}$ \\
\hline $\begin{array}{l}\text { Typologically- } \\
\text { ordered table }\end{array}$ & $\begin{array}{l}\text { Comparison of concepts by type } \\
\text { with descriptions and/or illustrative } \\
\text { evidence }\end{array}$ & + properties (of each concept) & Findings & $\begin{array}{l}\text { Augustine (2019, Table } 3) \\
\text { Kroezen and Heugens (2019, Table 1) } \\
\text { Zilber (2011, Table 4) }\end{array}$ \\
\hline $\begin{array}{l}\text { Theoretical } \\
\text { summary }\end{array}$ & $\begin{array}{l}\text { List of theoretical insights by } \\
\text { concept, by phase, etc. }\end{array}$ & $\begin{array}{l}\text { + description (of each insight) } \\
+ \text { selected examples }\end{array}$ & Findings & $\begin{array}{l}\text { Cloutier and Ravasi (2020, Table 4) } \\
\text { Dalpiaz, Rindova and Ravasi (2016, Table 4) }\end{array}$ \\
\hline
\end{tabular}


Table 2. Most common forms of evidence that can be put into table cells

\begin{tabular}{|c|c|c|}
\hline Form of evidence & Content types & Examples \\
\hline \multicolumn{3}{|l|}{ Raw data } \\
\hline \multirow[t]{2}{*}{ Text excerpts } & \multirow{2}{*}{$\begin{array}{l}\text { Direct quotes from interview transcripts; } \\
\text { document excerpts; field notes; tweets; etc. }\end{array}$} & Michel (2011, see Table 1) \\
\hline & & Sadeh and Zilber (2019, Tables 2 and 3) \\
\hline \multirow[t]{2}{*}{ Images } & \multirow{2}{*}{$\begin{array}{l}\text { Pictures, drawings or figures (if produced } \\
\text { by informants) }\end{array}$} & Ravasi, Rindova and Stigliani (2019, see Tables 7, 8 and 9) \\
\hline & & Pandza (2011, Table 2) \\
\hline \multicolumn{3}{|l|}{ Processed data } \\
\hline \multirow{2}{*}{$\begin{array}{l}\text { Narrative } \\
\text { summary }\end{array}$} & \multirow{2}{*}{$\begin{array}{l}\text { Concise account of observed events, } \\
\text { actions, decisions, outcomes, etc. }\end{array}$} & Bechky and Okhuysen (2011, see Table 3) \\
\hline & & Grodal (2018, see Table 4) \\
\hline \multirow[t]{2}{*}{ Numbers } & \multirow{2}{*}{$\begin{array}{l}\text { Total no. of occurrences, items, events, etc.; } \\
\text { percentages }\end{array}$} & Kellogg (2019, see Table 4) \\
\hline & & Croidieu and Kim (2018, see Table 3 ) \\
\hline \multirow{2}{*}{$\begin{array}{l}\text { Descriptive } \\
\text { codes }\end{array}$} & \multirow{2}{*}{$\begin{array}{l}\text { Acronyms, abbreviations, such as } \mathrm{Y} / \mathrm{N} \\
\text { (yes/no); M/F (male/female) etc. }\end{array}$} & Christianson (2019, Table 2) \\
\hline & & Hoppman, Naegele and Girod (2019, Table 3) \\
\hline \multirow[t]{2}{*}{ Symbols } & \multirow{2}{*}{$\begin{array}{l}\text { Tick marks or "like" symbol; full/half/no } \\
\text { circle; flag; etc. }\end{array}$} & Grimes (2018, see Table 2) \\
\hline & & Pache and Santos (2013, see Table 6) \\
\hline \multirow[t]{2}{*}{ Evaluations } & \multirow{2}{*}{$\begin{array}{l}\text { High/low; strong/medium/weak; } \\
\text { active/inactive; ++/--; etc. }\end{array}$} & Zimmermann, Raisch and Cardinal (2018, see Table 1) \\
\hline & & Cozzolino, Verona and Rothaermel (2018, Table 1) \\
\hline \multirow[t]{2}{*}{ Figures } & \multirow[t]{2}{*}{ Produced by the researcher } & Goh and Pentland (2019, see Table 3$)$ \\
\hline & & Nigam and Dokko (2019, see Table 5) \\
\hline
\end{tabular}


Table 4. Table types and trustworthiness: A summary

Table Type

Contributing to ensuring trustworthiness in the research process

Data inventory table

Data source table

Data analysis table

Event listing

Case summary table

Concept-evidence table

Coding scheme

Cross-case comparative table

Co-occurrence table

Temporally-ordered table

Typologically-ordered table

Theoretical summary
Helps researchers ensure they have collected all data required by their (evolving) study design; facilitates easy retrieval and use of data (no data item is inadvertently lost or misplaced) during analysis

Forces researchers to undertake a full accounting of data sources, and ensure all are used as fully as possible throughout the research process

Helps keep track and enables the reconstruction of analytical steps taken that led to emerging interpretations at different stages of the research process

Helps researchers ensure they have clearly and precisely established temporal sequence of relevant events

Helps ensure that researchers have reflected on contextual features that might have shaped observations

Helps ensure that researchers have made a conscious and systematic effort to ground their (possibly intuitive) interpretations in empirical evidence

Helps ensure that coding has been based on clearly stipulated criteria (rather than loose and blurry ones)

Facilitates systematic and thorough (rather than intuitive and superficial) comparisons across cases

Facilitates systematic tracking of the occurrence of one or several concepts across multiple cases

Facilitates systematic tracking of empirical support for claimed temporal patterns

Facilitates systematic tracking of similarities and differences in support of claimed typological differences Helps researchers document their efforts at articulating a theoretical explanation for their empirical observations
Contributing to build trust in the robustness of findings

Facilitates establishment of study audit trail

Facilitates the assessment of the credibility of data and data sources; helps ensure triangulation of sources

Helps assess the quality and thoroughness of the analytical process followed that links raw data to final conclusions

Facilitates the assessment of conclusions in light of contextual conditions (historical context)

Facilitates the assessment of conclusions in light of contextual conditions (organizational context)

Allows for disclosure of additional evidence in support of interpretations and claims; enables readers to independently assess extent of empirical support for theoretical claims

Helps demonstrate rigour of coding process; enables readers to independently assess if displayed evidence adequately represents stated criteria

Allows for the systematic display of evidence in support of cross-case variance claims; enables readers to independently assess these claims

Allows for effective display of co-occurrence patterns across multiple cases; enables readers to independently assess these patterns

Helps readers assess whether theoretical claims about temporal patterns correspond with empirical observations

Helps readers assess whether theoretical claims about typological patterns correspond with empirical observations Helps reassure readers of the analytical generalizability of a study's conclusions 
Figure 1. Table use over the course of a project

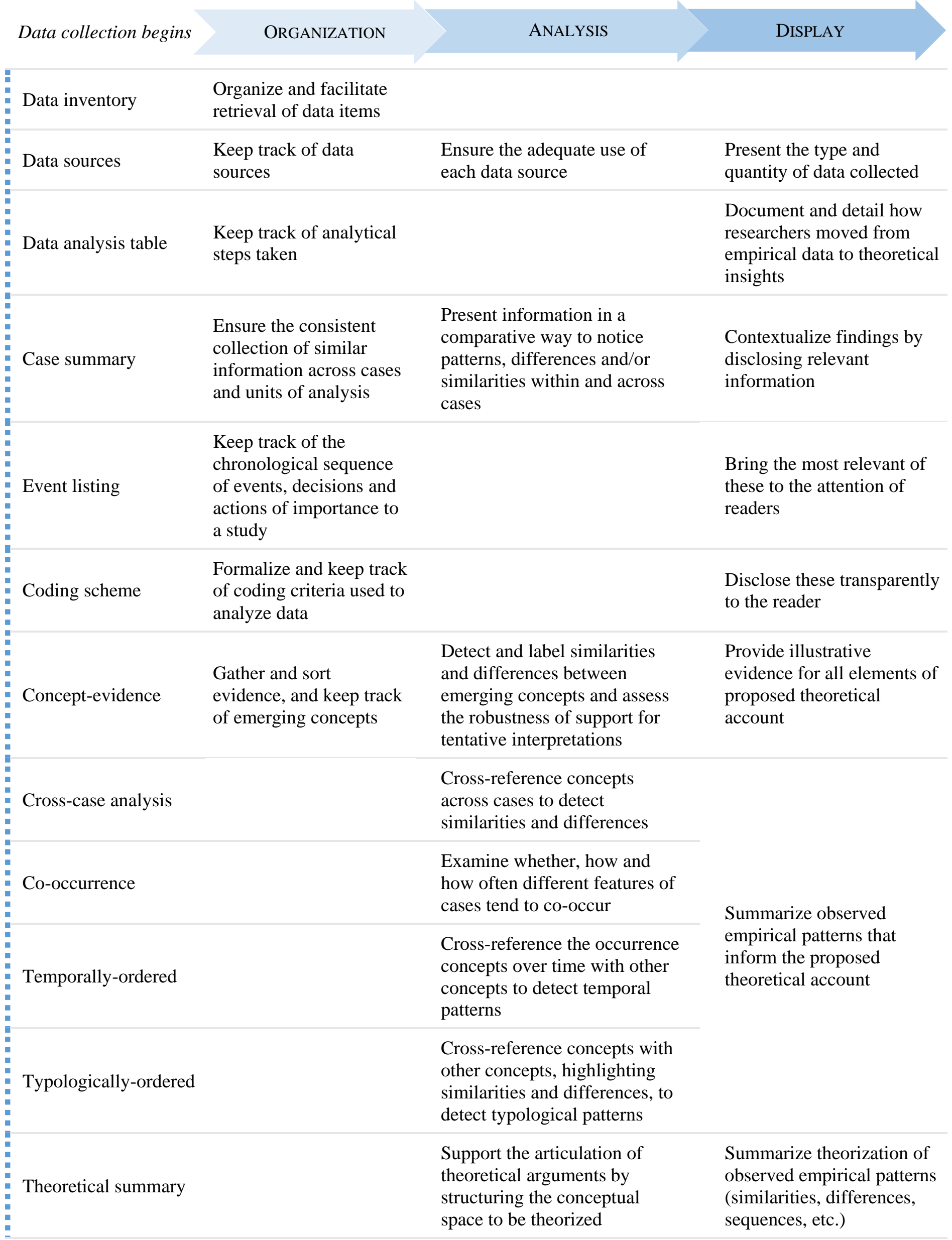




\section{Online Appendix}

\section{Using tables to support analysis: A behind-the-scenes tour}

In our own research on patterns of identity change in four nonprofit organizations (Cloutier and Ravasi, 2020), we used a vast range of tables to both organize and analyze our data. Some of these tables, in a polished form, eventually made it in the published paper. These include two tables that we had used to gather information about our informants, specifically, and our data sources, more generally, which were eventually merged into a single data sources and use table (Table 1, in Cloutier and Ravasi, 2020). Others did not: a case summary table, which we used to collect contextual information about our cases (year of foundation, size, number of employees, etc.), for instance, was eventually dropped, as we summarized relevant information in a single paragraph of the Methods section. Though many of the tables we used did not appear in the published paper they were nevertheless essential for supporting our analysis and theory development. To assume that we used only the tables displayed in the paper, or that we produced those tables solely for display purposes, would be a mistake. In this appendix, we provide a behind-the-scenes peek into some of the tables we designed and used for organization and analytical purposes and which eventually morphed into the display tables that appear in the paper.

Analysis for this paper began with a broad open coding of data (interview data to start, and then documentary data as well), during which we searched for any fragment of text that directly or indirectly referred to organizational identity - either in the form of identity claims (made by informants or others) or identity work (reference to actions aimed at articulating, disputing, maintaining, or altering identity beliefs). At this stage, we made ample use of concept-evidence tables to gradually collect and group evidence - which we directly cut and pasted from interview transcripts - associated with an emerging set of analytical codes, and to assess the 
quantity and completeness of the data we had in relation to these codes. On this basis, we could spot emerging patterns, and also see what was missing in the data. On this basis, we were able to redesign our study and return to the field to collect the data we needed to pursue and further develop interesting threads. As we did so, we gradually dropped some of these early tables as the concepts they contained (criteria used by funders to select projects and organizations to be funded or identity projection tactics, for example) seemed no longer relevant to our re-oriented purpose.

In one of these working tables, each row contained tentative codes (concepts) emerging from a first round of analysis (in the first column) and available evidence for each of the four cases we studied (see Table A1 for a generic example). Using a separate column for each case helped us have a quick visual appreciation of which codes were robustly supported across cases, and which only featured in some of them. Large white gaps in these tables - that is, empty cells in some columns, corresponding to cells full of evidence in other columns in the same row alerted us that some concepts were not consistently supported by all cases. These gaps actually helped reveal interesting variations across cases - i.e. some concepts only featured in two of the four cases, while others only featured in the other two - which eventually inspired our emerging explanatory framework.

The first column of each table included both a tentative label and a tentative definition for each analytical code to support the gradual theorization of our observations. Between each table and its title and to the same end, we also added evolving commentaries, which scholars also to refer to as memos, about the content of the table and its possible theoretical significance. We used this space also to gather excerpts from interviews or other textual data that might support our interpretations (for instance, by hinting at patterns, or suggesting sequences or causal mechanisms connecting analytical codes), without being direct evidence of a particular construct. As the analysis progressed, we also added a brief analytical summary of observations 
to each column that captured in a more holistic way the patterns highlighted by our analytical codes and help us reflect on what, at that stage, were still only partly unpacked first-order codes. This effort was important to clarify and articulate our transition from a descriptive to a theoretical analysis of cross-case differences.

Tables and the comments we attached to them were also an important way in which we communicated ideas and reflections with each other as co-authors. Comments written directly into a table or in its margins was an important way in which we kept track of and shared our respective interpretations of the emerging code structure and our theoretical insights. Some of these comments could be further developed and fleshed out and later be integrated into the main text of the paper.

A table that gained in importance over the course of our analysis was one that was initially designed to help us gather evidence of identity claims - statements about "who we are" made by the organization or one of its members - in each organization. At first, our interest was mainly descriptive: we wanted to gain a sense for how members and constituents of each organization understood and made claims about "who we are as an organization". As we built and populated these tables, we observed two important patterns: first, we noticed that each organization defined how similar or different they were from other organizations by combining different types of claims (which we eventually classified as category-based claims, role-based claims, and attribute-based claims, based on theories of individual and organizational identity) in different ways. Second, we noticed that the claims they made appeared to change over time. These observations drove the production of yet more elaborate tables - typologically and temporally ordered ones - to examine these insights in more depth.

Tables that gathered evidence of the different types of identity claims made by each of the cases we studied was eventually included in the published version of the paper. This was because the hierarchical structure of identity claims featured prominently in our explanatory 
framework. It was therefore important to clarify this aspect of our observations and provide adequate evidence to support it (see Tables 2 and 3 in Cloutier and Ravasi, 2020). These tables are typologically-ordered, to the extent that they organize evidence by type. In the course of the analysis, the two tables were actually combined into a single table showing how typological patterns differed across case (effectively, a typologically-ordered, cross-case comparative table). For the sake of clarity, however, we eventually decided to display evidence of typological patterns separately, and to use a theoretical summary, discussed later (Table 4 in Cloutier and Ravasi, 2020) to draw attention to cross-case variation in typological combinations.

By the same token, exploring longitudinal changes in these claims required us to build a number of temporally-ordered tables to construct and validate the trajectories followed by the identities of our four cases over several decades, with those that eventually did appear in the paper being produced only relatively late in the process. At an early stage, we had produced tables - one for each organization - condensing historical information and changing claims in a relatively intuitive way, mostly to serve as background information to our analyses. As we set out to analyze identity trajectories more closely, we produced a new set of tables to help us track changes in the content of identity statements as they were articulated in different organizational documents organized by type. Each row of the table referred to a different identity claim (which had been identified in a preliminary coding of the data, supported by concept-evidence tables as explained before) and each column to a different type of statement (mission statement, slogan, by-line, patent letters, etc.). In each cell, we cut and pasted all relevant data, ordered by time (yearly), so that we could easily see whether and how claims and statements had changed over time (see Table A2 in this appendix for an excerpt). Although these tables did not make it into the paper (they appeared as figures in intermediate versions see Figure A1 in this appendix for an example), they were absolutely crucial for helping us to 
systematically analyze the longitudinal evolution of identity claims. It was at this stage that we began tracking how new statements modified prior ones, and developed a classification scheme that helped us compare identity trajectories in a more systematic way than the intuitive one that had guided us until then.

Building on these tables, as we moved to a more explicit analytical effort, we then produced a new set of tables that tracked i) key events, such as the start or termination of areas of intervention, changes in leadership, moving into new premises, etc., ii) changes in identity statements (drawn from the previous tables), and iii) members' explanations (from interviews or archival sources) for why the statements had changed (something we referred to as "identity reflections") (see Table A3 in this appendix for an excerpt). These new tables were quite large (the one exemplified in Table A3 spanned seventeen pages in its original form), but they helped us reconstruct an accurate chronology of events that contextualized changes in identity claims. They also helped direct a new round of interviews aimed at filling gaps in our reconstructions and accounting for the changes we observed and informed our analysis of identity trajectories by offering us the contextual information we needed to classify different types of changes in identity statements we observed. A coding scheme helped us formalize the emerging classification criteria as we did so. This table was helpful to convey and exemplify our coding criteria in the course of the editorial process, and was eventually included in the appendix of the published paper (Table A1 in Cloutier and Ravasi, 2020).

Finally, we combined insights from previous tables to produce a third set of four tables that tracked changes in identity statements chronologically, labelled based on their type (e.g. reformulation, reinterpretation, etc.). A comparison among these four tables provided more robust support for our initial intuition that two cases differed from the other two in the type and frequency of changes that they had gone through since their foundation. These, once trimmed and formatted for display purposes, became another sets of tables included in the published 
version of the paper (see Cloutier \& Ravasi, Tables 5a, 5b, 5c, and 5c). As mentioned above, we initially produced these tables as figures: we believed that we could convey this information more effectively in a visual, rather than tabular form (see Figure A2 for a second example). Feedback from reviewers, however, made us realize that the more conventional format of tables made them easier to comprehend, and we transformed the figures into tables, to which reviewers responded positively.

As we pulled insights from all tables together and our interpretations gradually coalesced into a framework combining elements of process and variance (that is, offering an explanation of how a process - identity change vs. continuity - varied depending on the structure of identity claims at the time of foundation), we found a theoretical summary - a table structuring a theoretical comparison between how identity trajectories unfolded differently in the presence of different types of claims - particularly useful to support our theorization of these differences. This type of table was useful to help show how the different patterns we observed differed theoretically (and not just empirically), and for articulating a theoretical explanation for these differences. Eventually, we included this table in our paper (Table 4) to help readers grasp the essence of our theoretical arguments. 
Table A1. Structure of a concept-evidence working table used to verify evidence across cases (Cloutier \& Ravasi, 2020)

\begin{tabular}{|c|c|c|c|c|}
\hline Concepts & $\begin{array}{l}\text { Evidence from } \\
\text { Case } 1\end{array}$ & $\begin{array}{l}\text { Evidence from } \\
\text { Case } 2\end{array}$ & $\begin{array}{c}\text { Evidence from } \\
\text { Case } 3\end{array}$ & $\cdots$ \\
\hline \multirow[t]{3}{*}{$\begin{array}{l}\text { Concept } 1 \\
\text { (e.g. Identity } \\
\text { enforcement) }\end{array}$} & $\begin{array}{l}\text { "Quote from } \\
\text { interview" } \\
\text { (informant \#4) }\end{array}$ & $\begin{array}{l}\text { "Quote from } \\
\text { interview" } \\
\text { (informant \#3) }\end{array}$ & $\begin{array}{l}\text { "Quote from } \\
\text { interview" } \\
\text { (informant \#2) }\end{array}$ & $\ldots$ \\
\hline & $\begin{array}{l}\text { "Quote from } \\
\text { interview" } \\
\text { (informant \#6) }\end{array}$ & $\begin{array}{l}\text { "Quote from } \\
\text { interview" } \\
\text { (informant \#3) }\end{array}$ & $\begin{array}{l}\text { "Quote from } \\
\text { interview" } \\
\text { (informant \#12) }\end{array}$ & \\
\hline & $\begin{array}{l}\text { Excerpt from } \\
\text { (document \# 23) }\end{array}$ & $\begin{array}{l}\text { "Quote from } \\
\text { interview" } \\
\text { (informant \#9) }\end{array}$ & & \\
\hline \multirow{3}{*}{$\begin{array}{l}\text { Concept } 2 \\
\text { (e.g. Identity } \\
\text { enactment) }\end{array}$} & $\begin{array}{l}\text { Excerpt from } \\
\text { (document \# 12) }\end{array}$ & $\begin{array}{l}\text { Excerpt from } \\
\text { (document \# 13) }\end{array}$ & $\begin{array}{l}\text { Excerpt from } \\
\text { (document \# 17) }\end{array}$ & \\
\hline & $\begin{array}{l}\text { Excerpt from } \\
\text { (document \# 23) }\end{array}$ & $\begin{array}{l}\text { "Quote from } \\
\text { interview" } \\
\text { (informant \#9) }\end{array}$ & $\begin{array}{l}\text { Excerpt from } \\
\text { (document \# 21) }\end{array}$ & \\
\hline & $\begin{array}{l}\text { Excerpt from } \\
\text { (document \# } 270\end{array}$ & & & \\
\hline
\end{tabular}


Table A2. Excerpt of a working temporally-ordered table (date tracking in cells): Identity claims at Meals

\begin{tabular}{|c|c|c|c|c|}
\hline Claims & $\begin{array}{c}\text { Formal identity statements } \\
\text { (patent letters, mission, values) }\end{array}$ & $\begin{array}{l}\text { Corporate communication } \\
\text { (annual reports, newsletters, } \\
\text { websites, etc.) }\end{array}$ & Other internal documents & Interviews (members) \\
\hline $\begin{array}{l}\text { Meals-on- } \\
\text { wheels }\end{array}$ & $\begin{array}{l}\text { The objects of the corporations are: } \\
\text { 1) to provide a community, non- } \\
\text { profit, food delivery service to } \\
\text { persons experiencing a temporary } \\
\text { or permanent loss of self-autonomy } \\
\text { (Patent letters, 1996) } \\
\text { (...) }\end{array}$ & $\begin{array}{l}\text { The Meals-on-Wheels Program } \\
\text { remains the hub of the work we do } \\
\text { at Meals. (AR 2007) } \\
\text { Our Meals-on-Wheels is our first } \\
\text { program, the one around which the } \\
\text { organization was built back in } \\
1995 . . . \text { The meal service lies at } \\
\text { the heart of everything we do, and it } \\
\text { has carried our mission since our } \\
\text { inception } 16 \text { years ago (AR 2011) } \\
\text { (...) }\end{array}$ & $\begin{array}{l}\text { Our primary program is our } \\
\text { Intergenerational meals-on-wheels } \\
\text { program, a unique twist on a } \\
\text { traditional community service } \\
\text { which engages a diversity of people } \\
\text { in the community - while feeding } \\
\text { those in need (Organic evaluation, } \\
\text { 2002) } \\
(\ldots)\end{array}$ & $\begin{array}{l}\text { The original mission was really... } \\
\text { young people helping people with a } \\
\text { loss of autonomy through the } \\
\text { provision of healthy nutritious food } \\
\text { (SG, volunteer, 2005) } \\
\text { (...) }\end{array}$ \\
\hline $\begin{array}{l}\text { Youth } \\
\text { engagement }\end{array}$ & $\begin{array}{l}\text { An innovative, award-winning, } \\
\text { youth-run approach to building } \\
\text { healthy, connected communities. } \\
\text { We are framing a larger vision of } \\
\text { community development by linking } \\
\text { youth volunteerism and skills } \\
\text { development to youth engagement } \\
\text { (presentation, 2003) } \\
\text { Young People. Founded in } 1995 \text { by } \\
\text { a gaggle of passionate and } \\
\text { visionary young adults, Meals } \\
\text { continues to be operated and } \\
\text { sustained by the young (and the } \\
\text { young at heart!); we remain a } \\
\text { youth-centered organization } \\
\text { (website, section "Who we are", } \\
\text { 2014). } \\
\text { (...) }\end{array}$ & $\begin{array}{l}\text { SR is taking a leadership role in } \\
\text { mobilizing a generation of young } \\
\text { people to identify and address any } \\
\text { social issue relevant in their } \\
\text { community, creating the ability to } \\
\text { address deep community issues and } \\
\text { social challenges with confidence } \\
\text { (Annual Report 2002-2003) } \\
\text { By offering young people the } \\
\text { opportunity to develop leadership at } \\
\text { SR, we help build confidence and } \\
\text { skills, keep our organization } \\
\text { innovative and effective, and are } \\
\text { training a new generation of leaders } \\
\text { committed to positive change } \\
\text { (Annual Report 2008) } \\
\text { (...) }\end{array}$ & $\begin{array}{l}\text { The simple experience of delivering } \\
\text { meals to seniors can change the } \\
\text { way young people see the world. } \\
\text { This is one of the founding ideas } \\
\text { behind Meals (CG, co-founder - } \\
\text { Notes on the foundation of Meals, } \\
\text { 1998) } \\
\text { Youth engagement and } \\
\text { volunteerism is clearly our area of } \\
\text { "expertise" and it is in this area that } \\
\text { we feel we have a unique set of } \\
\text { knowledge and skills that would be } \\
\text { beneficial to share with other } \\
\text { organizations in this sector } \\
\text { (Applied Dissemination Project, } \\
\text { 2004) } \\
\text { (...) }\end{array}$ & $\begin{array}{l}\text { The ethos around young people } \\
\text { changing the world was really the } \\
\text { vision of the founders (...) young } \\
\text { people being able to create an } \\
\text { organization or to do good things } \\
\text { (JR, staff member). } \\
\text { You asked earlier, what's the } \\
\text { mission of Meals... and I said, you } \\
\text { know, that it was delivering meals } \\
\text { and intergenerational. Now after } \\
\text { reflection ... I think the real } \\
\text { mission of Meals is to give young } \\
\text { people amazing work experience } \\
\text { (WR, early volunteer, 2006) } \\
\text { (...) }\end{array}$ \\
\hline
\end{tabular}


Table A3. Excerpt of a working temporally-ordered table: Identity trajectory at Meals

\begin{tabular}{lll}
\hline $\begin{array}{l}\text { Organizational events } \& \\
\text { identity-defining actions }\end{array}$ & Identity reflections & Identity claims \\
\hline
\end{tabular}

1995. SR is founded in 1995 As we hashed away at ideas, by two recent university graduates who had been working as waiters in a trendy urban café.

(...)

2001. A new executive director Vanessa Reid initiates a revision of the mission, structure and policies.

An application for funding from a large donor triggers reflection about the nature of the organization, not only as a provider of social service, but as a promoter of social change.

\section{(...)}

2004. $S R$ is able to secure seed funding from another non-profit to build a garden on the roof of a nearby garage. The idea is to produce some of the food used into the meals delivered to seniors. The pilot attracts scores of volunteers and community interest. A second, and then a third rooftop garden soon follow. there was something that began to emerge as a central part of who we were and what we were doing. (...) we were trying to package the warmth and love of the Café and deliver it to people who were isolated from their own community. (CG, Notes on the foundation of Meals, 1998)

\section{(...)}

The way I was looking at it, [the meals-on-wheels] was just the beginning for asking deeper questions, for looking at a whole community's involvement in those questions, you know, questions around food security, citizenship, what is a community (VR, executive director, 2005).

\section{$(\ldots)$}

The theme always has been food, but we've gone from sort of service delivery of food to food security, I think that's... those are the two... within the mission, that have evolved. In the sense that now we're looking at organic farming, alternative farming, and ways to think about... you know... local issues related to food (SG, volunteer, 2005).
"The objects of the corporations are:

1) to provide a community, non-profit, food delivery service to persons experiencing a temporary or permanent loss of self autonomy;

2) to provide quality, nutritious and balanced meals to needy recipients;

3) to provide other programs from time to time to relieve poverty and assist needy or incapable persons in the community" (Patent letters) (...)

Corporate documents begin to underlie the "social change" mission of SR, and to theorize its "model for social change".

SR is a volunteer-based not-for-profit organization committed to building a healthy, viable intergenerational community by integrating and empowering youth and seniors, and building their capacities for civic engagement and social change (Funding application, 2001)."

\section{(...)}

The mission is updated:

SR is an award-winning community organization founded and run by young people. We use food as a vehicle to break social and economic isolation between the generations and to strengthen and nourish our local community. A social service with an environmental and social change ethos, SR aims to bring the most nutritious and ethically produced food to our community. We are innovating and experimenting with new ways of connecting people to food, to their environments and to each other [Unchanged until 2007]. 
Figure A1. Evolving Identity Statements at EQ, 1993-2014

\section{Patent letters}

1995 [The goal of the organizations is] to realize educational and research projects about the environment (Patent letters, 1995)

1999

2000

2002

2003

2004

2007

2012

2014 (Mission 2000-2002) 2003-2005)
Mission

Values

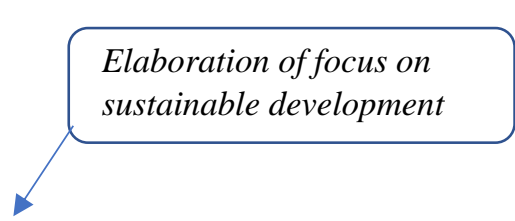

EQ is dedicated to promoting ecological and socially just choices through action, education and research from a standpoint that embraces social justice, economic solidarity and environmental protection

EQ is dedicated to building a citizen's movement, by promoting individual and collective choices that are environmentally friendly and socially just (Mission,

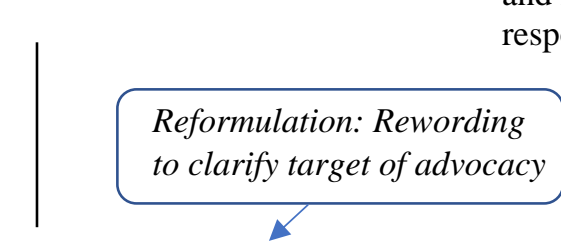

Five values related to the mission: Sustainable development, democracy, and individual and collective responsibility (Strategic Plan, 2003) elaboration of focus on influencing actions

Reformulation: Clarification of small steps approach

\section{1}

Other identity statements environmental protection, equality,

Addition: Articulation of dealmaker approach to corporate relationships

Contrary to other organizations, EQ does not wish to exclude a priori certain types of organizations, such as private enterprises (Ethical code, 2003, still in use)

Changing the world. One step at a time (Slogan 2004,

EQ helps build a social movement by encouraging individuals, organizations and governments to make ecological and equitable choices, in a spirit of solidarity (Mission, 2007, still in use) still in use)

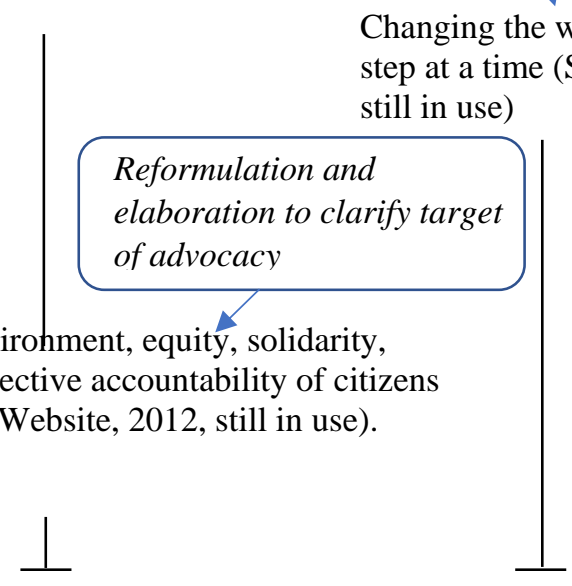

Defense of the environment, equity, solidarity, individual and collective accountability of citizens and governments (Website, 2012, still in use) 
Figure A2. Identity Trajectory and Evolving Identity Statements at Earth
CLAIMS
1995
2000
2005
2010
2015

Objects of the corporation: to realize educational and research projects about the environment (Patent Letters, 1996)

Sustainable

\section{development}

(1996 -)

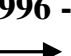

(2003 -)

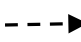

Small

steps

(2003 -)

$-\cdot \rightarrow$

Dealmakers

$(2003-)$
Earth is dedicated to promoting ecological and socially just choices through action, education and research from a standpoint that embraces social justice, economic solidarity and environmental protection (Mission 2000-2002)

Five values related to the mission: Sustainable development, democracy, environmental protection, equality, and individual and collective responsibility" (Strategic plan, 2003)
Elaboration of focus on sustainable development

\section{Reformulation (rewriting of} mission) and elaboration of focus on influencing actions

- Earth is dedicated to building a citizen's movement, by promoting individual and collective choices that are environmentally friendly and socially just (Mission, 2003-2005)
Reformulation and elaboration to clarify targets of advocacy efforts $\therefore$ Earth helps build a social movement by encouraging individuals, choices, in a spirit of solidarity (Mission, 2007, still in use)

Updated values: "Defense of the environment, equity, solidarity, individual and collective accountability of citizens and governments (Website, 2014)

\section{ironment, equity,}

Reformulation to make advocacy role more explicit 